\title{
The implementation strategy of customary law aspect in protecting local environment
}

\author{
Ratih Lestarini ${ }^{1, *}$, Tirtawening ${ }^{1}$, Riza Harmain $^{2}$, Succi Wulandhary ${ }^{2}$, and Dyah Utari $^{3}$ \\ ${ }^{1}$ Faculty of Law, Universitas Indonesia, Depok, Indonesia \\ ${ }^{2}$ School of Environmental Science, Universitas Indonesia, Salemba, Indonesia \\ ${ }^{3}$ Faculty of Health Science, Universitas Pembangunan Nasional Veteran Jakarta, Indonesia
}

\begin{abstract}
Environmental protection efforts have been made by the people, especially those still governed by customary law. Customary law serves to regulate society in all aspects of life, including the relationship between humans and between humans and the environment. The customary law also serves to regulate the use and the management of the environment efficiently for the purpose of preventing environmental damages and maintaining sustainability for the future. The communities which still have strong customary law will tend to preserve the environment and limit usages that cause damage to the environment. Cases of environmental damage that occurred today is very worrying. The formal law created is not sufficient to control it, so customary law is needed as an alternative to complementing the lack of formal law in order to effectively prevent the environmental damage. This research is aimed to determine the best way to protect the environment using customary aspect as the instrument. The method used in this paper is SWOT analysis that determines the strategies of the customary law in environment protection. The selection of the strategy was determined by the score and the weight of the pre-defined components. The results showed that the customary law, which has its own legal logic with aspects of local knowledge developed in the community for a long time as it relates to the values inherent culture and spiritualism, has a chance to be implemented in protecting environment. Customary law can be instrumental in preventing and protecting the environmental damage because the goal is to create harmony with nature.
\end{abstract}

\section{Introduction}

Policies or regulations are designed to protect people and society from the adverse effects arising from environmental problems [1]. The neighborhood is a place and role of human beings between living beings and other living components of the environment while environment is the unity of space and all objects, power, situation, and living creatures, including humans and their behavior, that affect the sustainability of our life. Environmental problems happening today are influenced by the growth of population and society, the high demand of natural resources that are exploitative in its extractions, and the

${ }^{*}$ Corresponding author: ratihlestarini@yahoo.com 
diverse development of technology and cultures between countries. In Indonesia,the protection of environment and the addressing of environmental problems is regulated in Law No. 23 of 2007 on Environmental Management. However, the implementations of the Law have not been able to maximally prevent environmental damage. Customary law serves to regulate the use and management of natural resources. This law is intended for the people to maintain and preserve their natural resources [2].

Almost all regions in Indonesia have customary law. The customary law regulates diverse aspects including on environmental management such as regulation on deforestation, wildlife hunting, forest-produce extraction, and forest protection. Customary law communities will manage the forest that serves as the source of life, using all its wisdom [3].

Customary law serves to regulate the use and management of natural resources. This law is intended for the people to maintain and preserve their natural resources [4]. One example of the use of customary law in addressing deadlock environmental cases is Customary Oath in Dayak Community. A customary oath is done by praying to their ancestors and asked them to punish anyone who changed their borders and territory [2]. Another example is the Sasi Law in Maluku Community. The Sasi Lawprohibits Sasi community to extract natural resources in a set period of time. Violation to this regulation will be punish by their ancestral spirits in the form of illness or it can be a physical punishment such as caning, fines, forced labor, and excluded from society. Sasi Law is still effective in preserving and protecting the environment. With the types of sanctions given, the community will not violate the law and will continue to keep the environment [5].

Environmental protection is an action to protect the environment from all forms of exploitation and in doing so there should be attention from the governments, academia, and individuals [6]. Environmental protection is a major issue in the discussion of environment sustainability. In the process of achieving sustainable development, environmental protection is an important integral development process and cannot be separated with sustainable development [7]. Environmental protection needs to make the laws of nature into consideration, in addition to environmental protection also need to be integrated with state laws and policies [8]. Laws of nature are considered regarding environmental protection to become the basic rule of human life, which later became the norms that develop within the public sphere. The norms evolving locally in the community will become customary law and be obeyed by the community and will have sanctions for those who violate them $[9,10]$. Customarylaw on environmental protection is potential to effectively suppress and reduce environmental damages caused by humans, and is also considered appropriate to support the lives of generations to come.

\section{Materials and Methods}

This research is aimed to determine the best way to protect the environment using customary aspect as the instrument. This research used SWOT analysis which consist of Strength (S), Weakness (W), Opportunity (O), and Threat (T). This research used SWOT Matrix to determine the conditions of the SWOT factors. The use of SWOT analysis in the study of law is to identify the strategic factors in the process of policy formulation [9]. The paradigm of this research is descriptive analysis and works on inductive logic. Tools to develop such a strategy is the SWOT matrix. SWOT matrix to produce four types of strategy, namely strategies SO (Strength-Opportunity), strategy WO (WeaknessOpportunity), the strategy of ST (Strength-Threats), and WT strategy (Weaknesses-Threats) [11]. By using SWOT analysis will additionally receive four types of strategies through internal and external factors that aggressive strategy (SO), competitive strategy (ST), a conservative strategy (WO), and defense strategy (WT). Determination of the weight is 
done through the deep interview from many experts, like stakeholders, religious leaders and environment activists, to get their judgment correspond to the reality. Therefore, the weight of the material which based on experts judgement is expected to correspond with the actual conditions and fit to reach the objective of the research.

\section{Result and Discussion}

In the case of strategy of implementation of customary law in protecting the environment thereats are strengths, weakness, opportunities, and threats to be addressed as follows:

a. Strengths: customary law can control people behavior and the interactions with nature. Customary law has strong connection between traditions and its believers.

b. Weakness: the role of customary law in environmental protection is still low. Customary law is not used as the main regulations for environmental protection instead of formal law.

c. Opportunity: customary law can protecting environment, customary law can strenghten the environmental law. Connection between traditions and believers in customary law expected to protect the environment effectively.

d. Threats: environmental sustainability can be threatened without a strong law. Strong connections in customary law can be used to reach environmental sustainability.

Based on the weighting that has been done, the matrix SWOT strategy of the dominant variable component consists of:

Table 1. SWOT matrix.

\begin{tabular}{|l|l|l|}
\hline \multicolumn{1}{|c|}{$\begin{array}{c}\text { S (Strength) } \\
\text { Internal strength factor } \\
\text { Tradition, religion, and faith) }\end{array}$} & $\begin{array}{l}\text { W (Weakness) } \\
\text { Internal vulnerability factor } \\
\text { (powerless and unclear } \\
\text { mechanism) }\end{array}$ \\
\hline $\begin{array}{l}\text { External opportunity } \\
\text { Factor } \\
\text { (Community } \\
\text { participation) }\end{array}$ & $\begin{array}{l}\text { SO strategy: create strategies } \\
\text { using control people's } \\
\text { behaviour and the interaction } \\
\text { with nature to protecting the } \\
\text { environment }\end{array}$ & $\begin{array}{l}\text { WO strategy: create } \\
\text { strategies that enhance the } \\
\text { role of customary law to } \\
\text { protecting the environment }\end{array}$ \\
\hline $\begin{array}{l}\text { T (Threat) } \\
\text { External Threats Factor }\end{array}$ & $\begin{array}{l}\text { ST strategy: create } \\
\text { strategiesusing control } \\
\text { prople's behaviour to prevent } \\
\text { the environmental problems }\end{array}$ & $\begin{array}{l}\text { WT strategy: create } \\
\text { strategies that enhance the } \\
\text { role of customary law to } \\
\text { prevent the environmat } \\
\text { problems }\end{array}$ \\
\hline
\end{tabular}

Table 1 about SWOT matrix describes how to define strategy based on Strength, Weakness, Opportunity, and Threats factors. Figure 1 describes the quadrant in the SWOT analysis. Quadrant 1 supports offensive strategy based on SO factor, quadrant 2 supports rational strategy based on WO factor, quadrant 3 supports diversification strategy based on ST factor, quadrant 4 supports defensive strategy based on WT strategy. 


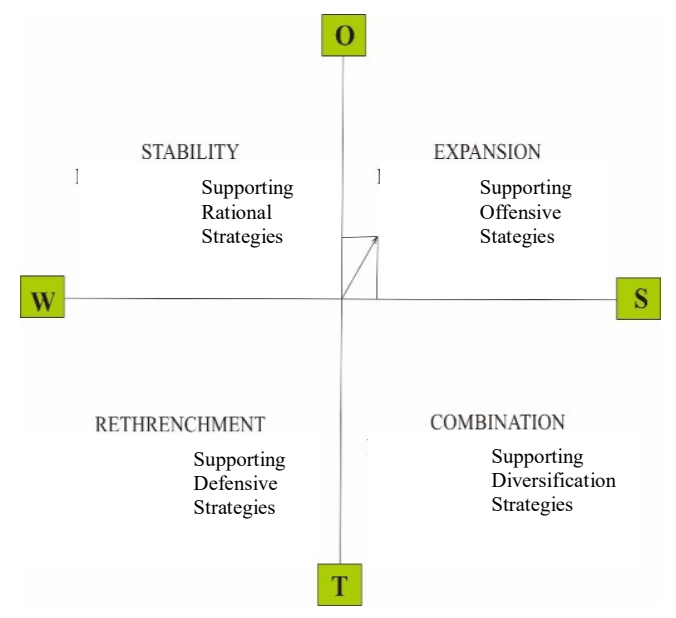

Fig. 1. SWOT matrix.

The result based on the SWOT analysis are the role of customary law in environmental protection is still weak, due to the assumption that customary law does not have strong connection, the assumption that customary law is left behind by formal law, and the absence of a clear mechanism which has effective systems and roles in the formal law towards the customary law which is a particular law. The weak role of customary law causes it can not control human behaviour and their interaction with the environment. Strategies are needed to reduce the weakness of customary law in environmental protection process by opening opportunity for the community to take part in environmental management, especially where the formal law is uncertain and unable to resolve environment problems. The expansion position can be done because the community's local wisdom can be used to create new approach in doing sustainable environmental management.

Other aspects of customary law that can be used in the protection and management of environment are tradition and religious aspect embedded in customary law. The autonomy regime also gives opportunity for customary law to be used in environmental protection. Customary law that is born and evolve from the community is significant to regulate and control the behavior of the community and their interactions with nature. This leads to a harmonious and balanced life. [12].

A minimum role of customary law in environmental protecting causes the meaning of customary law been ignored in environmental law, but the evidence that the existence of customary law is very important[13]. Customary law is a unique normative value that is always there and carried by the communityy, and always remain, but the customary law as a product that is not static and historic from the interaction between the actors and the environment. In another sense, the customary law has a power that is difficult to change because it has been present for generations and is formed through the relationship between human and nature. Customary law to question the way the interpretation, application, and determination of the results from the available resources, but the interpretation of customary law is more complex than the interpretation of state laws and other formal laws. [12]. Interpretation of customary law is more complex because it departs from myths or things that are not real, but has a binding power, while formal law departs from rational thinking by individuals and groups[14]. The customary law regulates many issues related to indigenous peoples property regulated by the state, for example, indigenous forests [16].

In addition to organizing indigenous forests, the customary law also gave the norms and customs of the sacred values of preservation and protection of life enjoyed by indigenous peoples. The customary law becomes an important element in addressing disputes and 
environmental issues. Environmental protection can be very effective when using the customary law. People living in a community with strong customary law will avoid to damage the environment. They will carry out their daily activities in the traditional way and in accordance with the customary law. This is considered as a form of public adherence to customary law in protecting their environment to remain sustainable.

Customary law is potential to be used because it has been present in the community for generations. The transfer of customary law knowledge from the previous generation to the next is done with full conscience and preservation. The values and norms in customary law is not in contrary with state laws therefore customary law is very feasible to be used in the management and protection of the environment]. Management and environmental protection that are based on customary laws are more flexible and made by consensus. It became the umpteenth factors which reinforce the position of customary law to be used in the protection and management of the environment [17]. However, of course, the customary law should receive extra attention by multi-stakeholder cooperation in environmental protection including environmental activists is one way to support the sustainability of the environment and the parties involved in it [18]. If these factors are considered properly, then the customary law can be used maximally and is potential as a role model for environmental protection laws.

\section{Conclusion}

Increasingly rampant cases of environmental destruction, such as illegal logging, illegal mining, illegal fishery etc, across the country alerts many people. The formal law available for environmental protection and management is not sufficient to reduce the destruction. However, there is an alternative to the lack of law regulating environment protection and management that is the use of local wisdom. Local wisdom is able to integrate both internal value and external value, to protect local value from outside interference and to control the development of the local community. This local wisdom needs to be studied further. The role of customary law that is based on local wisdom can fill the gaps in the formal law in preventing damage to the environment and this can be effectively enforced. The weak enforcement of formal law, such as blunt upward and sharp downward, gives an opportunity for customary law to be used in environmental protection. Through these conditions, gradual environmental sustainability can be manifested.

\section{Acknowledgements}

This research is funded by Ministries ff Research, Technology and Higher Education/Kemristekdikti 2018 with ProgramPenelitian Dasar Ungguan Perguruan Tinggi (PDUPT) 2018, contract number 275/UN.2.R3.1/HKP05.00/2018

\section{References}

1. C. Davis, Ext. Ind. Soc. 4, 63-68 (2017)

2. Z. Judge, M. Nurizka. Peranan hukum adat sasi laut dalam melindungi kelestarian lingkungan di Desa Eti Kecamatan Seram Barat Kabupaten Seram Bagian Barat. Lex Jurnalica 6, 1 (2008)

3. M. Sirait, C. Fay, A. Kusworo. Bagaimana hak-hak masyarakat hukum adat dalam mengelola sumber daya alam diatur. Southeast Asia Policy Research. Working Paper $\underline{\mathbf{2 4}},(2000)$ 
4. Philip Jacobson. Inside's Indonesia highest-profile land conflict. Retrieved April 4, 2018 from https://news.mongabay.com/2015/12/an-award-from-the-un-in-paris-butfighting-for-survival-in-borneo/

5. J. M. Ubink, In the land of the chiefs: customary law, land conflicts, and the role of the state in peri-urban Ghana (Leiden University Press, 2011)

6. A. Perreau-Saussine, J.B. Murphy, The nature of customary law (Cambridge University Press, 2007)

7. F.P. Maganga, Incorporating customary laws in implementation of IWRM: some insights from Rufiji River Basin, Tanzania. Physics and Chemistry of the Earth 28, (2003)

8. H.Y.S.H. Nugroho, A. Van Der Veen, A. Skidmore, Y.A. Hussin. Theoretical framework for spatial planning and forest management in Indonesia: securing the basic rights for adat people. Journal of Forestry Research 29, 2 (2018)

9. P. Hill. Environmental protection: What everyone needs to know (Oxford University Press, 2017)

10. D.K. Anton, D. Shelton, Environmental protection and human rights (Cambridge University Press, 2011)

11. L. Lavrysen. Environmental Law Syllabus. Ghent University

12. F.R. David, Strategic Management Concepts and Cases (Prentice-Hall Publishing, Francis Marion University, Florance, South Carolina, 2011).

13. M. Samejima, Y. Shimizu, M. Akiyoshi, N. Komoda. SWOT Analysis support tool for verification of bussiness strategy (Graduate School of Information Science and Technology, Osaka Univesity, Japan, 2006)

14. S.M Hatefi. trategic planning of urban transportation system based on sustainable development dimensions using an integrated SWOT and fuzzy COPRAS approach. Global Journal of Environmental Science and Management 4, 1 (2018)

15. M.I.F. Rahayu. Aspek hukum peran serta masyarakat adat dalam pengelolaan lingkungan hidup. Ethos 1, 1 (2003)

16. I.N. Sirtha, The Participation of Customary Law in The Sustainability of Regional Environment (Universitas Udayana, Bali, Indonesia, 2015)

17. N.L.K. Ni'mah, H. Herdiansyah, T.E.B.Soesilo, E.F. Mutia. Strategy for increasing the participation of masyarakat peduli api in forest fire control. IOP Conference Series: Earth and Environmental Science 126 012148, (2018)

18. D. Asteria, Budidarmono, H. Herdiansyah, N.L. Ni'mah. Gender sensitive education in watershed management to support environmental friendly city. IOP Conference Series: Earth and Environmental Science 126012146, (2018) 